\title{
Toxic cyanobacteria in reservoirs in northeastern Brazil: detection using a molecular method
}

\author{
Bittencourt-Oliveira, MC. ${ }^{\mathrm{a}}$, Santos, DMS. ${ }^{\mathrm{a}, \mathrm{b}}$ andMoura, $N A .^{\mathrm{b}}$ \\ ${ }^{a}$ Departamento de Ciências Biológicas, Escola Superior de Agricultura Luiz de Queiroz - ESALQ, \\ Universidade de São Paulo - USP, Av. Pádua Dias, 11, CP 9, CEP 13418-900, Piracicaba, SP, Brazil \\ ${ }^{b}$ Departamento de Biologia, Universidade Federal Rural de Pernambuco - UFRPE, CEP 52171-030, Recife, PE, Brazil \\ *e-mail: mbitt@esalq.usp.br \\ Received September 14, 2009 - Accepted February 3, 2009 - Distributed November 30, 2010
}

(With 2 figures)

\begin{abstract}
Cyanobacterial blooms are a frequent occurrence in northeastern Brazil and constitute a serious public health problem. Using the polymerase chain reaction (PCR) method, eleven environmental samples with cyanobacteria from seven reservoirs were used to determine the presence of the gene involved in microcystin biosynthesis ( $m c y \mathrm{~B}$ ). Two sets of oligonucleotide primers were designed from the sequencing of Brazilian populations of microcystin producing cyanobacteria $(m c y \mathrm{~B}-\mathrm{F} / \mathrm{R}$ and $m c y \mathrm{~B}-\mathrm{F} / \mathrm{R}-\mathrm{A})$. The presence of the $m c y \mathrm{~B}$ gene involved in microcystin biosynthesis was found in all samples, indicating the potential of this gene for producing the toxin. The PCR method proved sensitive and appropriate for the detection of potential producers of microcystins in environmental samples. Its ability to reveal potentially toxic cyanobacteria demonstrates that it can be a valuable tool in the monitoring of blooms.
\end{abstract}

Keywords: northeast Brazil, mcyB, microcystin, molecular markers, environmental monitoring.

\section{Cianobactérias tóxicas em reservatórios do nordeste do Brasil: detecção utilizando método molecular}

\section{Resumo}

Florações de cianobactérias são frequentes no nordeste do Brasil, constituindo um sério problema de Saúde Pública. Através da utilização da técnica de PCR, onze amostras ambientais com cianobactérias provenientes de sete reservatórios foram utilizadas para verificar a presença de um dos genes envolvido na biossíntese de microcistina ( $m c y \mathrm{~B})$. Para isso foram utilizados dois conjuntos de oligonucleotídeos primers ( $m c y \mathrm{~B}-\mathrm{F} / \mathrm{R}$ e $m c y \mathrm{~B}-\mathrm{F} / \mathrm{R}-\mathrm{A})$ desenhados a partir de sequências de populações brasileiras de Microcystis produtoras de microcistina. A presença do gene $m c y \mathrm{~B}$ foi verificada em todas as amostras analisadas, indicando a capacidade de produzir esta toxina. O método de PCR apresentou-se sensível e apropriado para a detecção de potenciais produtores de microcistinas em amostras ambientais. Sua habilidade em detectar genótipos indicadores de produção de microcistina nos reservatórios investigados sugere que este método pode auxiliar no monitoramento de florações.

Palavras-chave: nordeste do Brasil, mcyB, microcistina, marcadores moleculares, monitoramento ambiental.

\section{Introduction}

Cyanobacterial blooms in public water supply reservoirs have become a matter of ever increasing concern throughout the world due to their potential for producing toxins. Water scarce semiarid northeast reservoirs, coupled with cultural eutrophication, have given rise to a recurring bloom formation of toxin-producing cyanobacterial species (Bouvy et al., 2000; Chellappa et al., 2000; 2008a, b; Costa et al., 2006; Panosso et al., 2007). The infrequent rainfall pattern, its heterogeneous distribution, punctuated by prolonged and intense dry periods, have all caused drought polygon in water storage in reservoirs of this region (Almeida et al., 2009). The occurrence of cyanobacterial blooms is therefore due to the combination of diverse factors and are favoured by high temperatures, high light intensities and run-off from agro-fertilizers originating from inadequate agricultural procedures around these bodies of water.

Microcystin is a cyanotoxin associated with a number of cases of intoxication in animals and humans. The worst case involving a human population occurred in the city of Caruaru in northeastern Brazil, in which patients at a hospital had been exposed to microcystins (Jochimsen et al., 1998). Brazilian legislation imposes the monitoring of bodies of water for public supply. This monitoring should

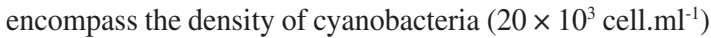


and maximum acceptable level of microcystin of $1 \mu \mathrm{g} . \mathrm{L}^{-1}$ in drinking water (Regulation MS N.518/2004).

Microcystin production depends on the existence of genes that codify microcystin synthetase. Microcystin is a hepatotoxin produced by a non-ribosomal pathway through a polyketide synthase/non-ribosomal peptide synthetase (PKS/NRPS) complex known as microcystin synthetase, which is responsible for the incorporation of amino acids in the peptide chain (Kleinkauf and von Döhren, 1996; Dittmann et al., 1997). The mcy gene cluster is responsible for toxin production, coding for microcystin synthetase (Dittmann et al., 1997; Tillett et al., 2000). Some cyanobacteria are unable to produce toxins, but all those that have genes associated to microcystin biosynthesis should be viewed as potential toxin producers (Ouellette et al., 2006).

Kurmayer et al. $(2002,2004)$ found that a few strains of cyanobacteria in nature have no microcystin production, but contain all the genes for microcystin synthetase. The authors speculate that these strains had lost the ability to synthesise microcystin due to gene inactivation and that another small peptide could functionally substitute this toxin.

A large number of authors have used microcystin synthetase genes ( $m c y)$ as molecular markers for microcystinproducing cyanobacteria (Baker et al., 2002; Nonneman and Zimba, 2002; Bittencourt-Oliveira, 2003; Hisbergues et al., 2003), for, in other studies, the presence of microcystin has been correlated, almost without exception, to the presence of mcy genes (Kurmayer and Kutzenberger, 2003; Via-Ordorika et al., 2004; Dittmann and Börner, 2005). There are no morphological differences between toxic and non-toxic cyanobacteria. Thus, the early detection of toxic cyanobacteria in water resources is advisable in order to avoid contamination and public health problems. Predicting toxic blooms is quite important in view of both their increasing occurrence in large water supply systems and the high cost of the current technology used for their removal.

The aim of the present study was to evaluate the existence of microcystin-producing genotypes using the molecular marker for the $m c y \mathrm{~B}$ gene in public water supply reservoirs.

\section{Material and Methods}

Eleven environmental samples were collected with a $25 \mu \mathrm{m}$ mesh plankton net from seven public water supply reservoirs in northeastern Brazil (Figure 1, Table 1). The cyanobacterial bloom-forming was determined from morphological characteristics used for the identification of taxa.

DNA was extracted from fresh cells of the environmental samples following the procedure described by Rogers and Bendich (1985). Polymerase chain reaction (PCR) was performed in a GeneAmp PCR System 9700 thermocycler (Applied Biosystems, Foster City, CA, USA) using pure Taq Ready-To-Go PCR Beads kits (Amersham, Piscataway, NJ, USA) with $20 \mu \mathrm{M}$ of each oligonucleotide ( $m c y \mathrm{~B}-\mathrm{F} / \mathrm{R}$ and $m c y \mathrm{~B}-\mathrm{F} / \mathrm{R}-\mathrm{A})$. For PCR amplification, the following cycling parameters were used: $94{ }^{\circ} \mathrm{C}$ for 2 minutes, 35 cycles at $94{ }^{\circ} \mathrm{C}$ for 10 seconds; $50^{\circ} \mathrm{C}$ for 20 seconds, and $72{ }^{\circ} \mathrm{C}$ for 1 minute, followed by a final extension at $72{ }^{\circ} \mathrm{C}$ for 5 minute. The oligonucleotide primers were designed using sequences from Brazilian populations of microcystinproducing Microcystis. All primers were synthesised by IDT (Medley, FL, USA).

As a positive control, amplification reactions with oligonucleotide primers were used for the phycocyanin operon (PC) (Neilan et al., 1995) following the procedure described by Baker et al. (2001). Amplification products were visualised by electrophoresis on $0.7 \%$ agarose gels stained with ethidium bromide $\left(0.2 \mu \mathrm{g} . \mathrm{mL}^{-1}\right)$ in $1 \mathrm{X}$ TBE running buffer and recorded using the Electrophoresis Documentation and Analysis System 290 (EDAS 290)

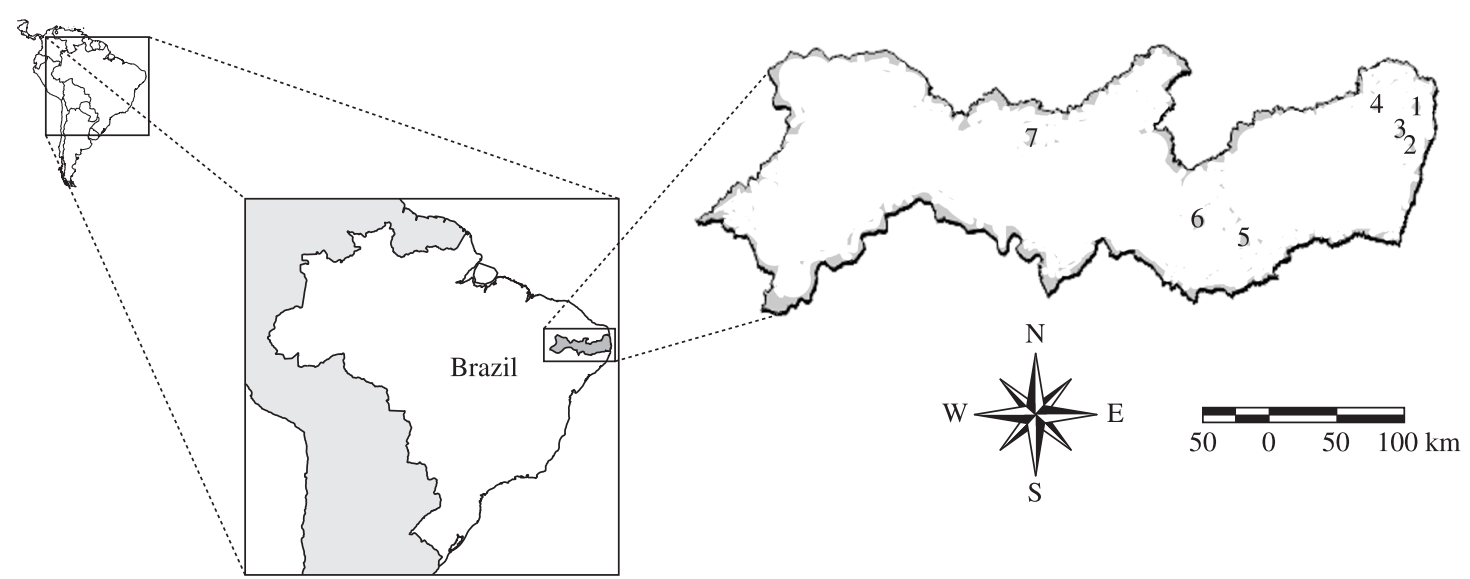

Figure 1. Map of study areas; Reservoirs: 1. Botafogo; 2. Duas Unas; 3.Tapacurá; 4. Carpina; 5. Mundaú; 6. Arcoverde; 7. Jazigo; State of Pernambuco, northeastern Brazil. 
(Kodak, Melville, NY, USA). In all reactions sets, a control treatment (without DNA) was included (data not shown). All tests were performed in duplicate. The reproducibility band was tested with DNA from different extractions using the same methodology and conditions. Fragments obtained from the primers $m c y \mathrm{~B}-\mathrm{F} / \mathrm{R}$ and $m c y \mathrm{~B}-\mathrm{F} / \mathrm{R}-\mathrm{A}$ resulted in sizes with approximately 570 and $315 \mathrm{bp}$, respectively.

\section{Results}

Potential microcystin-producing cyanobacteria were identified in the seven reservoirs investigated (Table 2). The prevailing species were Microcystis aeruginosa (Kützing) Kützing, $M$. novacekii (Komárek) Compère, $M$. panniformis Komárek et al., Anabaena constricta (Szafer) Geitler and Planktothrix agardhii (Gomont) Anagnostidis \& Komárek.

The mcyB gene involved in microcystin biosynthesis was found in all samples. The oligonucleotide primer $m c y \mathrm{~B}-\mathrm{F} / \mathrm{R}-\mathrm{A}$ revealed a higher number of unexpected bands (Table 2 and Figure 2).

\section{Discussion}

Microcystis aeruginosa, M. novacekii, M. panniformis, Planktothrix agardhii and species from the genus Anabaena are frequent in bodies of water in Brazil. However, not all these organisms or populations necessarily have a potential for microcystin production. The presence of microcystin synthetase genes does not necessarily indicate the production of microcystins, but it does indicate the potential for their production. Recent studies have demonstrated that some strains have no capacity for toxin production because they do not have the entire $m c y$ gene cluster (Christiansen et al., 2008).

The evaluation of the genetic potential for microcystin production can be determined by investigating the presence of $m c y$ genes, for microscopic analysis does not allow the distinction of microcystin-producing from non-microcystinproducing organisms. Studies using ELISA (BittencourtOliveira, 2003; Hisbergues et al., 2003; Vaitomaa et al., 2003), MALDI-TOF MS (Kurmayer et al., 2002; Saker et al., 2005), HPLC (Nonneman and Zimba, 2002; Ouahid et al.,

Table 1. Sampling locations and dates used.

\begin{tabular}{|c|c|c|c|}
\hline Reservoirs & Latitude & Longitude & Sampling date \\
\hline Arcoverde & $8^{\circ} 333^{\prime} 33^{\prime \prime} \mathrm{S}$ & $36^{\circ} 59^{\prime} 07^{\prime \prime} \mathrm{W}$ & Mar. 1, 2005 \\
\hline Arcoverde & $8^{\circ} 33^{\prime} 33^{\prime \prime} \mathrm{S}$ & $36^{\circ} 59^{\prime} 07^{\prime \prime} \mathrm{W}$ & Aug. 23, 2006 \\
\hline Botafogo & $7^{\circ} 53^{\prime} 02 ” \mathrm{~s}$ & $35^{\circ} 03^{\prime} 32^{\prime \prime} \mathrm{W}$ & Oct. 18, 2006 \\
\hline Duas Unas & $8^{\circ} 05^{\prime} 31^{\prime \prime} \mathrm{S}$ & $35^{\circ} 02,19^{\prime \prime} \mathrm{W}$ & Oct. 17,2006 \\
\hline Carpina & $7^{\circ} 533^{\prime} 51^{\prime \prime} \mathrm{S}$ & $35^{\circ} 20^{\prime} 13^{\prime \prime} \mathrm{W}$ & Feb. 13, 2006 \\
\hline Carpina & $7^{\circ} 53,51 ” \mathrm{~S}$ & $35^{\circ} 20^{\prime} 13^{\prime \prime} \mathrm{W}$ & Aug. 26, 2006 \\
\hline Carpina & $7^{\circ} 53^{\prime} 51^{\prime \prime} \mathrm{S}$ & $35^{\circ} 20^{\prime} 13^{\prime \prime} \mathrm{W}$ & Sep. 18, 2006 \\
\hline Jazigo & $7^{\circ} 59^{\prime} 58^{\prime \prime} \mathrm{S}$ & $38^{\circ} 14^{\prime} 31^{\prime \prime} \mathrm{W}$ & Mar. 3, 2005 \\
\hline Mundaú & $8^{\circ} 57^{\prime} 17^{\prime \prime} \mathrm{s}$ & $36^{\circ} 29^{\prime} 55^{\prime \prime} \mathrm{W}$ & Sep. 19, 2006 \\
\hline Tapacurá & $8^{\circ} 02^{\prime} 14^{\prime \prime} \mathrm{S}$ & $35^{\circ} 09^{\prime} 46^{\prime \prime} \mathrm{W}$ & Aug. 26, 2004 \\
\hline Tapacurá & $8^{\circ} 02,14 ” \mathrm{~S}$ & $35^{\circ} 09^{\prime} 46^{\prime \prime} \mathrm{W}$ & Oct. 16, 2006 \\
\hline
\end{tabular}

Table 2. Presence (+) or absence (-) of amplified fragments using the oligonucleotide primers designed for Brazilian populations of cyanobacteria $(m c y \mathrm{~B}-\mathrm{F} / \mathrm{R}, m c y \mathrm{~B}-\mathrm{F} / \mathrm{R}-\mathrm{A}) .\left({ }^{*}\right)$ Non-specific fragments.

\begin{tabular}{|c|c|c|c|c|}
\hline Reservoirs & Most frequent cyanobacteria & PC & $\begin{array}{c}m c y \\
\text { B-F/R }\end{array}$ & $\begin{array}{c}m c y \\
\text { B-F/R-A }\end{array}$ \\
\hline Arcoverde & Cylindrospermopsis raciborskii (Woloszynska) Seenaya \& Subba Raju & + & + & + \\
\hline Arcoverde & Planktothrix agardhii (Gomont) Anagnostidis \& Komárek & + & + & $+*$ \\
\hline Botafogo & Microcystis aeruginosa (Kützing) Kützing & + & - & $+^{*}$ \\
\hline Duas Unas & Anabaena constricta (Szafer) Geitler & + & + & $+*$ \\
\hline Carpina & Cylindrospermopsis raciborskii (Woloszynska) Seenaya \& Subba Raju & + & + & + \\
\hline Carpina & Microcystis aeruginosa (Kützing) Kützing, M. panniformis Komárek et al. & + & + & + \\
\hline Carpina & Microcystis aeruginosa (Kützing) Kützing, M. panniformis Komárek et al. & + & + & + \\
\hline Jazigo & Geitlerinema amphibium (Ag. ex Gom.) Anagnostidis & + & + & $+*$ \\
\hline Mundaú & Microcystis aeruginosa (Kützing) Kützing & + & $+*$ & $+*$ \\
\hline Tapacurá & Cylindrospermopsis raciborskii (Woloszynska) Seenaya \& Subba Raju & + & + & + \\
\hline Tapacurá & Microcystis aeruginosa (Kützing) Kützing & + & + & + \\
\hline
\end{tabular}



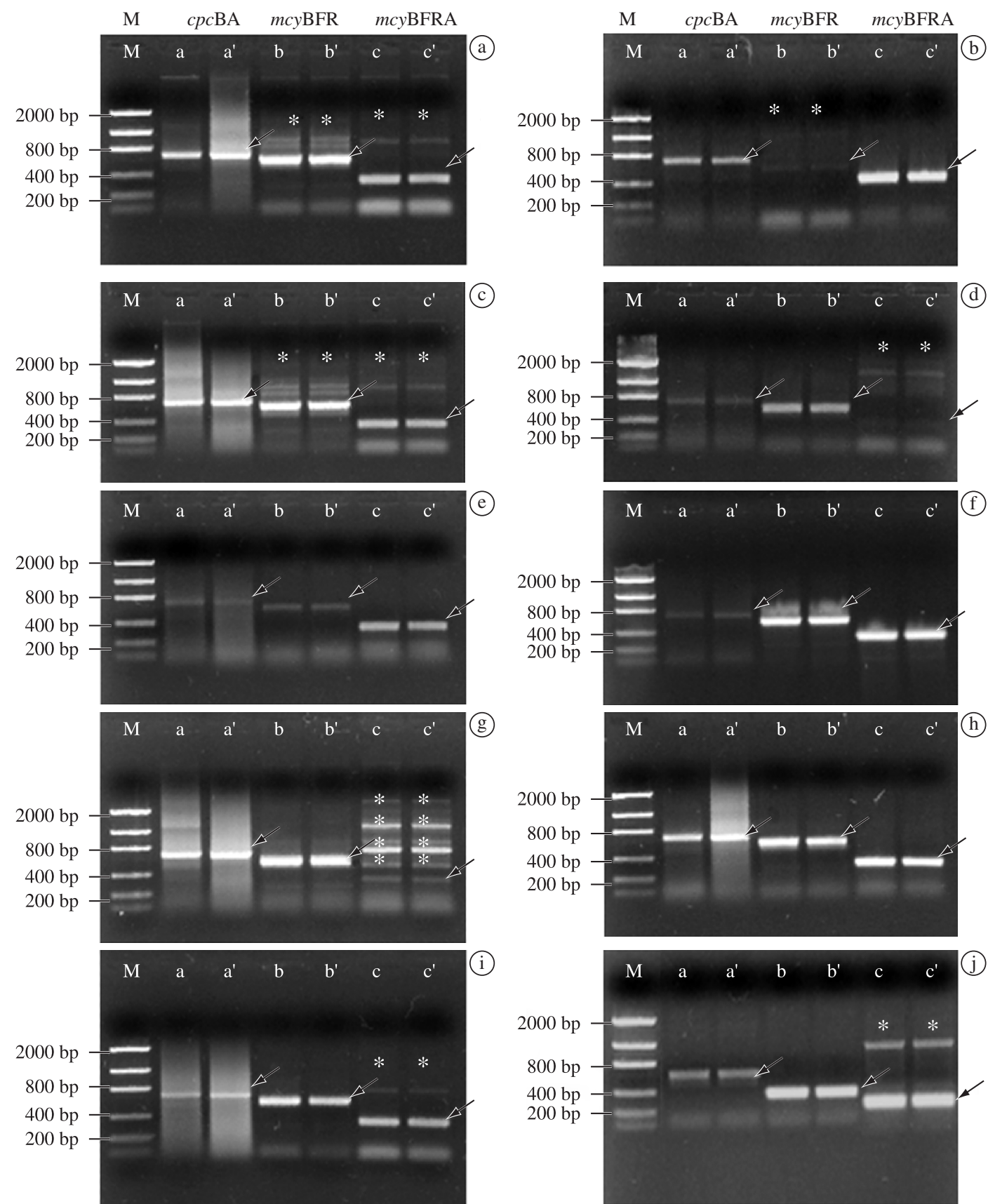

Figure 2. Amplification products (with replicas) revealed in electrophoresis with $0.7 \%$ agarose gels; Lanes M are DNA molecular mass standards (Low DNA); Lanes a-a': $c p c$ BA; Lanes b-b': $m c y B-F / R ;$ Lanes c-c': $m c y$ B-F/R-A; Expected fragment (arrow); non-specific fragment (asterisk); a) Arcoverde Aug 23, 2006; b) Mar 1, 2005; c) Mundaú Sep 19, 2006; d) Jazigo Mar 3, 2005; e) Tapacurá Oct 16, 2006; f) Tapacurá Aug 26, 2004; g) Botafogo Oct 18, 2006; h) Carpina Aug 26, 2006; i) Duas Unas Oct 17, 2006; and j) Carpina Feb 13, 2006.

2005) and bioassays with mice (Baker et al., 2002; Pan et al., 2002) have confirmed the production of microcystin in cyanobacteria with $m c y$ genes. However, recent studies report the presence of amplified fragments in samples in which microcystins were not detected through highperformance liquid chromatography (HPLC) (Saker et al.,
2007; Ouahid et al., 2005; Mankiewicz-Boczek et al., 2006). There are a number of interpretations for this, such as microcystin-producing genotypes that are not expressed (Kurmayer and Kutzenberger, 2003; Bittencourt-Oliveira, 2003), or the toxin is present but at concentrations below the HPLC detection limit. 
The occurrence of these inactive microcystin genotypes is rare and poorly understood, but this should not be a significant limitation to the applicability of molecular detection. In previous studies, the presence of microcystin has been correlated, almost without exception, to the presence of mcy genes (Kurmayer and Kutzenberger, 2003; Via-Ordorika et al., 2004; Dittmann and Börner, 2005).

The presence of non-specific bands in the samples using $m c y \mathrm{~B}-\mathrm{F} / \mathrm{R}-\mathrm{A}$ did not impede the correct reading of the results obtained, since the size of the expected marker was previously known. Among the oligonucleotide primers tested, $m c y \mathrm{~B}-\mathrm{F} / \mathrm{R}$ proved to be more specific than $m c y \mathrm{~B}$ F/R-A, as it did not exhibit non-specific bands.

Molecular analysis confirms the need for the monitoring of water quality in public water supply reservoirs in Brazil due to the occurrence of genotypes indicating toxicity. The PCR method was sensitive and appropriate for the detection of potential microcystin-producing cyanobacteria in environmental samples. The method could be used either alone or in conjunction with other techniques, such as the screening of samples to be sent for quantitative toxicological analysis using HPLC, thereby reducing monitoring cost and time. The usefulness of this molecular method in the investigation of potentially toxic cyanobacteria in reservoirs suggests that PCR could be a valuable tool in the monitoring of blooms.

Acknowledgements - This study was supported by grants from FAPESP (The State of São Paulo Research Foundation - MCBO: 2006/03878-6, and CNPq (Brazilian Council for Research and Development-MCBO: 300794/2004-5).

\section{References}

ALMEIDA, VLS., DANTAS, ÊW., MELO-JÚNIOR, M., BITTENCOURT-OLIVEIRA, MC. and MOURA, AN., 2009. Zooplanktonic community of six reservoirs in northeast Brazil. Revista Brasileira de Biologia = Brazilian Journal of Biology, vol. 69 , no.1, p. 57-65.

BAKER, JA., ENTSCH, B., NEILAN, BA. and McKAY, DB., 2002. Monitoring changing toxigenicity of a cyanobacterial bloom by molecular methods. Applied and Environmental Microbiology, vol. 68 , no. 12 , p. $6070-6076$

BAKER, JA., NEILAN, BA., ENTSCH, B. and McKAY, DB., 2001. Identification of cyanobacteria and their toxigenicity in environmental samples by rapid molecular analysis. Environmental Toxicology, vol. 16, no. 6, p. 472-482.

BITTENCOURT-OLIVEIRA, MC., 2003. Detection of potencial microcystin-producing cyanobacteria in Brazilian reservoirs with a mcyB molecular marker. Harmful Algae, vol. 2, p. 51-60.

BOUVY, M., FALCÃO, D., MARINHO, M., PAGANO, M. and MOURA, A., 2000. Occurrence of Cylindrospermopsis (Cyanobacteria) in 39 Brazilian tropical reservoirs during the 1998 drought. Aquatic Microbial Ecology, vol. 23, p. 13-27.

CHELLAPPA, NT., CHELLAPPA, SL. and CHELLAPPA, S., 2008a. Harmful phytoplankton blooms and fish mortality in a eutrophicated reservoir of Northeast Brazil. Brazilian Archives of Biology and Technology, vol. 51, no. 4, p. 833-841.
CHELLAPPA, NT., BORBA, JM. and ROCHA, O., 2008 b. Phytoplankton community and physical-chemical characteristics of water in the public reservoir of Cruzeta, RN, Brazil. Revista Brasileira de Biologia = Brazilian Journal of Biology, vol. 68, no. 3, p. 477-494.

CHELLAPPA, NT., COSTA, MAM. and MARINHO, IR., 2000. Harmful cyanobacterial blooms from semiarid freshwater ecosystems of North-East Brazil. Australia. Australian Society for Limnology, vol. 38, no. 2, p. 45-49.

CHRISTIANSEN, G., MOLITOR, C., PHILMUS, B. and KURMAYER, R., 2008. Nontoxic strains of cyanobacteria are the result of major gene deletion events induced by a transposable element. Molecular Biology and Evolution, vol. 25, no. 8, p. 1695-1704

COSTA, IAS., AZEVEDO, SMFO., SENNA, PAC., BERNARDO, RR., COSTA, SM. and CHELLAPPA, NT., 2006. Occurrence of toxin-producing cyanobacteria blooms in a Brazilian semiarid reservoir. Revista Brasileira de Biologia = Brazilian Journal of Biology, vol. 66, no. 1B, p. 211-219.

DITTMANN, E. and BÖRNER, T., 2005. Genetic contributions to the risk assessment of microcystin in the environment - lessons from biosynthesis genes. Toxicology and Applied Pharmacology, vol. 203 , no. 3 , p. $192-200$.

DITTMANN, E., NEILAN, BA., ERHARD, M., von DÖHREN, H. and BÖRNER, T., 1997. Insertional mutagenesis of a peptide synthetase gene that is responsible for hepatotoxin production in the cyanobacterium Microcystis aeruginosa PCC 7806. Molecular Microbiology, vol. 26, no. 4, p. 779-787.

HISBERGUES, M., CHRISTIANSEN, G., ROUHIAINEN, L., SIVONEN, K. and BÖRNER, T., 2003. PCR-based identification of microcystin-producing genotypes of different cyanobacterial genera. Archives of Microbiology, vol. 180, no. 6, p. 402-410.

JOCHIMSEN, EM., CARMICHAEL, WW., AN, J., CARDO, DM., COOKSON, ST., HOLMES, CEM., ANTUNES, MBC., MELO-FILHO, DA., LYRA, TM., BARRETO, VST., AZEVEDO, SMFO. and JARVIS, WR., 1998. Liver failure and death after exposure to microcystin at a hemodialysis center in Brazil. New England Journal of Medicine, vol. 338, no. 13, p. 873-878.

KLEINKAUF, H. and von DÖHREN, H., 1996. A non-ribosomal system of peptide biosynthesis. European Journal of Biochemistry, vol. 236 , no. 2 , p. 335-351.

KURMAYER, R. and KUTZENBERGER, T., 2003. Application of real-time PCR for quantification of microcystin genotypes in a population of the toxic cyanobacterium Microcystis sp. Applied and Environmental Microbiology, vol. 69, no. 11, p. 6723-6730.

KURMAYER, R., CHRISTIANSEN, G., FASTNER, J. and BÖRNER, T., 2004. Abundance of active and inactive microcystin genotypes in populations of the toxic cyanobacterium Planktothrix spp. Environmental Microbiology, vol. 6, no. 8, p. 831-841.

KURMAYER, R., DITTMANN, E., FASTNER, J. and CHORUS, I., 2002. Diversity of microcystin genes within a population of the toxic cyanobacterium Microcystis spp. in Lake Wannsee (Berlin, Germany). Microbial Ecology, vol. 43, no. 1, p. 107-118.

MANKIEWICZ-BOCZEK, J., IZYDORCZYK, K., ROMANOWSKA-DUDA, Z., JURCZAK, T., STEFANIAK, K. and KOKOCINSKI, M., 2006. Detection and monitoring toxigenicity of cyanobacteria by application of molecular methods. Environmental Toxicology, vol. 21, no. 4, p. 380-387. 
NEILAN, BA., JACOBS, D. and GOODMAN, AE., 1995. Genetic diversity and phylogeny of toxic cyanobacteria determined by DNA polymorphisms within the phycocyanin locus. Applied and Environmental Microbiology, vol. 61, no. 11, p. 3875-3883.

NONNEMAN, D. and ZIMBA, PV., 2002. A PCR-based test to assess the potential for microcystin occurrence in channel catfish production ponds. Journal of Phycology, vol. 38, no. 1, p. 230-233.

OUAHID, Y., PÉREZ-SILVA, G. and DEL CAMPO, F., 2005. Identification of potentially toxic environmental Microcystis by individual and multiplex PCR amplification of specific microcystin syntethase gene regions. Environmental Toxicology, vol. 20, no. 3 , p. 235-242.

OUELLETTE, AJ., HANDY, SM. and WILHELM, SW., 2006. Toxic Microcystis is widespread in Lake Erie: PCR detection of toxin genes and molecular characterization of associated cyanobacterial communities. Microbial Ecology, vol. 51, no. 2, p. $154-165$.

PAN, H., SONG, L., LIU, Y. and BÖRNER, T., 2002. Detection of hepatotoxic Microcystis strains by PCR with intact cells from both culture and environmental samples. Archives of Microbiology, vol. 178 , no. 6 , p. 421-427.

PANOSSO, R., COSTA, IAS., SOUZA, NR., ATTAYDE, JL., CUNHA, SRS. and GOMES, FCF., 2007. Cianobactérias e cianotoxinas em reservatórios do estado do Rio Grande do Norte e o potencial controle das florações pela tilápia do Nilo (Oreochromis niloticus). Oecologia Brasiliensis, vol. 11, no. 3, p. 433-449.

Regulation MS n. 518/2004, 2004. Guidelines for Drinking Water Quality. Official Law Reports, 26 Mar. 2004. Section I, 266 p.
ROGERS, SO. and BENDICH, AJ., 1985. Extraction of DNA from milligram amounts of fresh, herbarium an mummified plant tissues. Plant and Molecular Biology, vol. 5, no. 2, p. 69-76.

SAKER, ML., FASTNER, J., DITTMANN, E., CHRISTIANSEN, G. and VASCONCELOS, VM., 2005. Variation between strains of the cyanobacterium Microcystis aeruginosa isolated from a Portuguese river. Journal of Applied Microbiology, vol. 99, no. 4, p. 749-757.

SAKER, ML., VALE, M., KRAMER, D. and VASCONCELOS, VM., 2007. Molecular techniques for the early warning of toxic cyanobacteria blooms in freshwater lakes and rivers. Applied Microbiology and Biotechnology, vol. 75, no. 2, p.441-449.

TILLETT, D., DITTMANN, E., ERHARD, M., von DÖHREN, H., BÖRNER, T. and NEILAN, BA., 2000. Structural organization of microcystin biosynthesis in Microcystis aeruginosa PCC7806: an integrated peptide-polyketide synthetase system. Chemistry \& Biology, vol. 7, no. 10, p. 753-764.

VAITOMAA, J., RANTALA, A., HALINEN, K., ROUHIAINEN, L., TALLBERG, P., MOKELKE, L. and SIVONEN, K., 2003. Quantitative real-time PCR for determination of microcystin synthetase e copy numbers for Microcystis and Anabaena in lakes. Applied and Environmental Microbiology, vol. 69, no. 12, p. 7289-7297.

VIA-ORDORIKA, L., FASTNER, J., KURMAYER, R., HISBERGUES, M., DITTMANN, E., KOMÁREK, J., ERHARD, M. and CHORUS, I., 2004. Distribution of microcystin-production and non-microcystin-production Microcystis sp in European freshwater bodies: detection of microcystins and microcystins genes in individual colonies. Systematic and Applied Microbiology, vol. 27 , no. 5 , p. 592-602. 